\title{
Enrichment and Selection of Hydantoinase-producing Micro-organisms
}

\author{
By ANDRÉ MORIN, $†$ WERNER HUMMEL \\ MARIA-REGINA KULA* $\ddagger$ \\ Gesellschaft für Biotechnologische Forschung mbH, Mascheroder Weg 1, D-3300 Braunschweig- \\ Stöckheim, Federal Republic of Germany
}

(Received 10 November 1986; revised 5 January 1987)

\begin{abstract}
A screening method that allows rapid, efficient and reliable detection and selection of hydantoinase-positive micro-organisms was devised. Out of 76 strains selectively isolated from soil, 15 strains possessing hydantoin-hydrolysing activity were selected using a spot-test based on the direct detection in agar of $\mathrm{N}$-carbamyl amino acids. The results obtained were confirmed by quantitative determination of hydantoinase activity in whole cells and crude extracts of positive strains. Inactivity and/or instability of some hydantoin-hydrolysing activity were observed upon preparation of a few crude extracts. Preliminary experiments indicated that some selected strains had an inducible hydantoinase activity. The reliability and the indicative value (presence of hydantoinase) of the spot-test were confirmed by incubating crude extracts in enzyme membrane reactors for up to $112 \mathrm{~h}$. The six strains that were positive with the spot-test and had high hydantoinase activity continuously produced $N$-carbamylvaline. Following nitrite treatment of $N$-carbamylvaline, only $\mathrm{D}$-valine could be detected as confirmed by three different methods (enzymic and chromatographic).
\end{abstract}

\section{INTRODUCTION}

Hydantoinase (dihydropyrimidinase; EC 3.5.2.2) catalyses the opening of the ring of dihydropyrimidine and several 5-monosubstituted hydantoins to give $N$-carbamyl amino acids (Yamada et al., 1978). This reaction appears to be especially useful for the production of Damino acids. In contrast to similar reactions (e.g. acylase, esterase), yields of more than $50 \%$ can be obtained with hydantoinase because of the spontaneous racemization of the D- and Lenantiomers under special conditions. Conversion of the resulting $N$-carbamyl amino acids into amino acids can then be achieved by reaction with nitrite (Takahashi et al., 1979).

Reactions catalysed by hydantoinase are described in the literature so far for whole cells and/or crude extracts (Cotoras \& Wagner, 1984; Sun 1983; Yamada et al., 1978), mostly from Pseudomonas strains. As the hydantoinase reaction involves only one enzyme, it is advantageous to use it in an immobilized state, for instance in an enzyme membrane reactor (Wandrey \& Flaschel, 1979), as developed for animoacylase and fumarase (Leuchtenberger et al., 1984).

We have described the laboratory-scale continuous production of $N$-carbamylvaline from isopropylhydantoin in an enzyme membrane reactor over a $10 \mathrm{~d}$ period. The hydantoinase used in this experiment was isolated from Pseudomonas fluorescens strain DSM 84 (Morin et al., $1986 c$ ). However, application of a great number of well-known purification methods revealed that most of the hydantoinase activity of strain DSM 84, which is high and stable in the crude extract, is lost during separation from the other proteins (Morin et al., 1986c). The present paper describes the isolation of soil micro-organisms possessing high hydantoinase activity. A number

\footnotetext{
† Present address: Agriculture Canada, Centre de recherches alimentaires de Saint-Hyacinthe, 3600 boul. Casavant Ouest, Saint-Hyacinthe, Québec, Canada J2S 8E3.

$\ddagger$ Present address: Institut für Enzymtechnologie der Universität Düsseldorf in der KFA Jülich, Postfach 2050, D-5170 Jülich 1, Federal Republic of Germany.
} 
of enrichment procedures was used not only to obtain a variety of micro-organisms, but also to investigate the conditions which favour the growth of hydantoinase-producers among the hydantoin-degrading micro-organisms.

\section{METHODS}

Microbial strains. These were isolated from soil (from around Braunschweig) and plated on different media incubated under different conditions as described below.

Media and culture conditions for the isolation of hydantoin-hydrolysing micro-organisms. These are summarized in Table 1. Hydantoin-degrading micro-organisms were enriched in liquid medium $\mathrm{H} 2$ adjusted to $\mathrm{pH} 7.0$ containing $\left(1^{-1}\right): 2.0 \mathrm{~g}$ hydantoin, $5.0 \mathrm{~g} \mathrm{~K} \mathrm{HPO}_{4} .3 \mathrm{H}_{2} \mathrm{O}, 0.1 \mathrm{~g}$ sodium citrate. $2 \mathrm{H}_{2} \mathrm{O}, 0.2 \mathrm{~g} \mathrm{MgSO}_{4} .7 \mathrm{H}_{2} \mathrm{O}, 0.5 \mathrm{~g}$ yeast extract and $2.0 \mathrm{ml}$ of the following trace elements solution $\left(\mathrm{mg} \mathrm{l}^{-1}\right): \mathrm{ZnSO}_{4} \cdot 7 \mathrm{H}_{2} \mathrm{O}(11), \mathrm{MnSO}_{4} \cdot 1 \mathrm{H}_{2} \mathrm{O}$ (6), $\mathrm{FeSO}_{4} .7 \mathrm{H}_{2} \mathrm{O}(1), \mathrm{CoSO}_{4} .7 \mathrm{H}_{2} \mathrm{O}(0.3), \mathrm{CuSO}_{4} .5 \mathrm{H}_{2} \mathrm{O}(0.04), \mathrm{H}_{3} \mathrm{BO}_{3}(0.06)$ and $\mathrm{KI}(0.001)$. The enrichment cultures were plated on medium $\mathrm{K}$ adjusted to $\mathrm{pH} 7.0$ containing $\left(1^{-1}\right): 5 \mathrm{~g}$ yeast extract, $5 \mathrm{~g}$ corn steep liquor (as dried powder), $5 \mathrm{~g}$ glycerol, $2 \mathrm{~g} \mathrm{~K}_{2} \mathrm{HPO}_{4}, 2 \mathrm{~g}$ hydantoin and $20 \mathrm{~g}$ agar. For isolation methods 6 and 7 (Table 1), microorganisms were enriched in acidic and alkaline medium respectively, in which the $\mathrm{pH}$ of media $\mathrm{H} 2$ and $\mathrm{K}$ was adjusted with sterile phosphoric acid or sodium carbonate to $\mathrm{pH} 4.0$ or 10.0 . For enrichment of drought-resistant micro-organisms (method 4), the soil sample was dried for $180 \mathrm{~min}$ at $60^{\circ} \mathrm{C}$. For isolation of sporulating organisms (methods 1,2 and 3), a suspension of the soil sample $\left(1 \mathrm{~g}\right.$ in $9 \mathrm{ml}$ saline) was heated for $10 \mathrm{~min}$ at $80^{\circ} \mathrm{C}$. All samples were cultured under aerobic conditions in $500 \mathrm{ml}$ Erlenmeyer flasks with two baffles at 130 r.p.m. Unless otherwise stated, cultures were incubated at $27^{\circ} \mathrm{C}$. Each culture from each method was subcultured two to five times.

Detection of hydantoinase-producing strains on solid media. The microbial strains isolated were inoculated to produce single colonies on agar medium K and incubated for 18 to $24 \mathrm{~h}$ at 27,37 or $55^{\circ} \mathrm{C}$, according to the source and conditions of isolation. One replica was prepared for each plate that contained isolated colonies in order to test subsequently for ability to hydrolyse the substrate dihydrouracil. Hydantoinase-positive strains were detected using a spot-test that allowed immediate detection in agar of $\mathrm{N}$-carbamyl amino acids (Morin et al., 1986a). Positive strains developed an unequivocal yellow colour after 5 to $10 \mathrm{~s}$ reaction with the aldehyde solution.

Preparation of cell suspensions and crude extracts. After cultivation in $100 \mathrm{ml}$ of medium $\mathrm{K}$, cells were collected by centrifugation and the pellet was resuspended in $0.1 \mathrm{M}$-potassium phosphate buffer, $\mathrm{pH} 8.0$, as a $20 \%(\mathrm{w} / \mathrm{w})$ suspension. Cell samples $(1.0 \mathrm{ml})$ were disrupted by grinding with glass beads $(2.0 \mathrm{~g})(0.1$ to $0.25 \mathrm{~mm}$ diameter $)$ at $0{ }^{\circ} \mathrm{C}$ for $15 \mathrm{~min}$. Centrifugation gave clear, crude extracts which were then tested for enzyme activity.

Hydantoinase assay. Cell suspensions $(20 \%, \mathrm{w} / \mathrm{w})$ or crude extracts were tested for hydantoin-hydrolysing activity (Yamada et al., 1978). The reaction mixture contained one of four substrates [ $100 \mu \mathrm{mol}$ dihydrouracil or $100 \mu \mathrm{mol}$ hydantoin (Sigma); $100 \mu \mathrm{mol} 5$-isoprophylhydantoin or $5 \mu \mathrm{mol} 5-p$-hydroxybenzylhydantoin (Degussa, Hanau, FRG)] plus $100 \mu \mathrm{mol}$ Tris $/ \mathrm{HCl}$ buffer, $\mathrm{pH} 8.0,20 \mu \mathrm{mol} \mathrm{NaCl}$ and $1.0 \mathrm{ml}$ of cell suspension. The total volume of the reaction mixture was $2.0 \mathrm{ml}$. The reaction mixture was incubated for $30 \mathrm{~min}$ at $30^{\circ} \mathrm{C}$ with reciprocal shaking. The reaction was stopped with $0.5 \mathrm{ml} 12 \%(\mathrm{w} / \mathrm{w})$ trichloroacetic acid solution and $10 \%(\mathrm{w} / \mathrm{w})$ p-dimethylaminobenzaldehyde acidic solution $(6.0 \mathrm{M}-\mathrm{HCl})$. The amount of $N$-carbamyl amino acids formed was estimated from the absorbance at $450 \mathrm{~nm}$. One enzyme unit (U) was defined as $1 \mu \mathrm{mol} N$-carbamyl amino acid formed $\mathrm{min}^{-1}$. All enzyme assays were done in duplicate.

Protein assay. Protein in the crude extracts was determined by the method of Bradford (1976) using bovine serum albumin as a standard. All protein assays were done in triplicate.

Induction of hydantoinase activity. The effect of possible inducers of hydantoinase was determined using crude extracts of strains 1-2, 1-9, 1-15, 2-2, 2-5 and 10-3. These strains were grown in medium $\mathrm{K}$ without hydantoin containing as potential inducer $0.1 \%$ of one of the following substrates: hydantoin, isopropylhydantoin, $p$ hydroxybenzylhydantoin, uracil or dihydrouracil. Crude extracts of these cultures were then assayed for hydantoinase using isopropylhydantoin as substrate.

Determination of the stereospecificity of the hydantoin-hydrolysing activity.

Enzyme membrane reactor. A laboratory-scale enzyme membrane reactor (Hummel et al., 1983) was used to evaluate the stereospecificity of the hydantoinase. The reaction vessel $(10.0 \mathrm{ml}$ final volume $)$ contained $50 \mathrm{~mm}$ isopropylhydantoin and $20 \mathrm{mM}-\mathrm{NaCl}$, dissolved in $0.1 \mathrm{M}-\mathrm{Tris} / \mathrm{HCl}$ buffer, $\mathrm{pH} 8.0$, and $5 \mathrm{ml}$ of one of the crude extracts. The reactor was fitted with a YM5 Amicon membrane ( $M_{\mathrm{r}}$ cut-off 5000). The reaction mixture from the reaction vessel was filtered at a flow rate of $1 \cdot 9,3 \cdot 8,1 \cdot 9,5 \cdot 0,4.9$ and $5.0 \mathrm{ml} \mathrm{h}^{-1}$ for strains $1-2,1-9,1-15,2-2,2-5$ and 10-3 respectively. The substrate solution (the same as that of the reaction vessel but without the enzyme) was continuously fed into the reaction vessel to replace the ultrafiltrate. The optical rotation of the product in the ultrafiltrate was continuously determined in a polarimeter (Perkin Elmer 241 ) at $25^{\circ} \mathrm{C}$ and $436 \mathrm{~nm}$. The first 40 to $50 \mathrm{ml}$ of ultrafiltrate were discarded and the remaining ultrafiltrates were lyophilized and stored at $-20{ }^{\circ} \mathrm{C}$.

Conversion of $N$-carbamylvaline. A sample $(100 \mathrm{mg})$ of lyophilized ultrafiltrate was resuspended in $5.0 \mathrm{ml}$ $0.05 \mathrm{M}$-potassium phosphate buffer, $\mathrm{pH} 8.0$; samples $(2 \mathrm{ml})$ of this solution were used to determine the optical 
Table 1. Isolation of hydantoin-hydrolysing micro-organisms.

\begin{tabular}{|c|c|c|c|c|c|}
\hline $\begin{array}{l}\text { Isolation } \\
\text { method }\end{array}$ & $\begin{array}{l}\text { Enrichment } \\
\text { medium* }\end{array}$ & $\begin{array}{l}\text { Isolation } \\
\text { medium* }\end{array}$ & $\begin{array}{l}\text { No. of } \\
\text { strains } \\
\text { isolated }\end{array}$ & $\begin{array}{l}\text { No. of } \\
\text { hydantoinase- } \\
\text { positive } \\
\text { strains }\end{array}$ & $\begin{array}{l}\text { Strain } \\
\text { number }\end{array}$ \\
\hline 1 & $\mathrm{H} 2$ & $\mathrm{~K}$ & 9 & 1 & $8-1$ \\
\hline 2 & $\begin{array}{l}\mathrm{H} 2+10 \mathrm{~g} \\
\text { glycerol } \mathrm{I}^{-1}\end{array}$ & $\begin{array}{l}\mathrm{K}+10 \mathrm{~g} \\
\text { glycerol } \mathrm{l}^{-1}\end{array}$ & 6 & 0 & - \\
\hline 3 & $\begin{array}{l}\mathrm{H} 2+2 \cdot 5 \mathrm{~g} \\
\mathrm{NH}_{4} \mathrm{Cl}^{-1}\end{array}$ & $\begin{array}{l}\mathrm{K}+2 \cdot 5 \mathrm{~g} \\
\mathrm{NH}_{4} \mathrm{ClI}^{-1}\end{array}$ & 7 & 1 & $7-1$ \\
\hline 4 & $\mathrm{H} 2$ & $\mathrm{~K}$ & 9 & 1 & $5-1$ \\
\hline 5 & $\begin{array}{l}\mathrm{H} 2+20 \mathrm{~g} \\
\text { hydantoin } \mathrm{l}^{-1}\end{array}$ & K & 4 & 0 & - \\
\hline 6 & $\mathrm{H} 2, \mathrm{pH} 4.0$ & $\mathrm{~K}, \mathrm{pH} 4.0$ & 3 & 0 & - \\
\hline 7 & $\mathrm{H} 2, \mathrm{pH} 10 \cdot 0$ & $\mathrm{~K}, \mathrm{pH} 10.0$ & 4 & 4 & $\begin{array}{l}11-1,11-2 \\
11-3,11-4\end{array}$ \\
\hline 8 & $\mathrm{H} 2,10^{\circ} \mathrm{C}$ & K & 6 & 1 & $1-2$ \\
\hline 9 & $\mathrm{H} 2,15^{\circ} \mathrm{C}$ & $\mathrm{K}$ & 4 & 1 & $1-9$ \\
\hline 10 & $\mathrm{H} 2,37^{\circ} \mathrm{C}$ & K & 3 & 0 & - \\
\hline 11 & $\mathrm{H} 2,55^{\circ} \mathrm{C}$ & $\mathrm{K}, 50^{\circ} \mathrm{C}$ & 5 & 2 & $10-1,10-3$ \\
\hline 12 & $\begin{array}{l}\mathrm{H} 2+100 \mu \mathrm{g} \\
\text { penicillin } \mathrm{ml}^{-1}\end{array}$ & $\mathrm{~K}$ & 5 & 2 & $1-15,2-2$ \\
\hline 13 & $\begin{array}{l}\mathrm{H} 2+5 \mathrm{mg} \\
\text { polymyxin B ml-1 }\end{array}$ & K & 5 & 2 & $2-5,2-6$ \\
\hline \multirow[t]{2}{*}{14} & $\begin{array}{l}\mathrm{H} 2+100 \mu \mathrm{g} \\
\text { streptomycin } \\
\text { sulphate } \mathrm{ml}^{-1}\end{array}$ & K & 6 & 0 & - \\
\hline & & Total & 76 & 15 & \\
\hline
\end{tabular}

${ }^{*}$ Medium $\mathrm{H} 2$ and medium $\mathrm{K}$ are described in Methods. Unless otherwise stated, the incubation temperature was $27^{\circ} \mathrm{C}$ and the $\mathrm{pH}$ was 7.0 .

rotation value and the amount of $N$-carbamylvaline using the methods described above. Samples $(2 \mathrm{ml})$ were used to prepare valine from $N$-carbamylvaline using the following method. $\mathrm{HCl}(3.5 \mathrm{M})$ and an amount of $\mathrm{NaNO}_{2}$ equivalent to the $N$-carbamylvaline determined with the $p$-dimethylaminobenzaldehyde reagent were added to the sample at room temperature. The mixture was evaporated to dryness in vacuo and resuspended in $0.5 \mathrm{ml}$ deionized water.

Amino acid oxidase test. The amounts of D- and L-valine obtained by the hydrolysis of $N$-carbamylvaline were determined enzymically using the amino acid oxidase ( $\mathrm{L}-$ and $\mathrm{D}-$ ) reactions. The reaction mixture comprised $3.0 \mathrm{ml}$

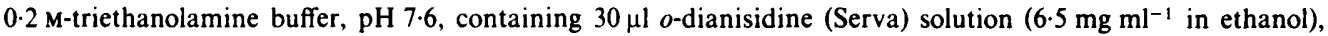
$20 \mu \mathrm{l}$ peroxidase ( $160 \mathrm{U} \mathrm{ml}^{-1}$; Boehringer), $10 \mu \mathrm{l} \mathrm{L}$ - or $20 \mu \mathrm{l} \mathrm{D-amino} \mathrm{acid} \mathrm{oxidase} \mathrm{(Boehringer)} \mathrm{and} 50 \mu \mathrm{l}$ of nitritetreated $N$-carbamylvaline solution. The reaction mixture was incubated for $30 \mathrm{~min}$ at $25^{\circ} \mathrm{C}$ and the absorbance at $436 \mathrm{~nm}$ compared to a calibration curve obtained with $\mathrm{D}$ - or L-valine respectively.

Enantiomeric resolution by $T L C$. (Günther $e t$ al., 1984.) Samples $(2 \mu \mathrm{l})$ of hydrolysates of $N$-carbamyl amino acids were applied to a Chiralplate (C) (Macherey-Nagel, Düren, FRG) activated for $15 \mathrm{~min}$ at $100^{\circ} \mathrm{C}$. Samples of Dand L-valine, $N$-carbamyl-DL-valine (Sigma) and isopropylhydantoin (Degussa) were used as controls. The plates were run for $30 \mathrm{~min}(13 \mathrm{~cm})$ using methanol/water/acetonitrile $(50: 50: 200$, by vol.). The spots were visualized by spraying with $0.1 \%$ ninhydrin (Merck) and heating at $100^{\circ} \mathrm{C}$ for $10 \mathrm{~min}$.

\section{RESULTS}

Different isolation methods were used to screen soil samples for hydantoinase-producing micro-organisms under different conditions (see Table 1). Colonies were isolated under all medium and culture conditions used: spore-forming micro-organisms (methods 1,2 and 3), drought-resistant micro-organisms (method 4), acidophiles (method 6), alkalophiles (method 7), psychrophiles (methods 8 and 9), mesophiles (method 10), thermophiles (method 11), Grampositive bacteria (methods 13 and 14), Gram-negative bacteria (12 and 14) and aerobes (all methods) were obtained. Of 76 strains isolated, 15 possessed hydantoin-hydrolysing activity. These positive isolates were given a number and were further screened with regard to the amount and to the spectrum of their activity. 
Table 2. Hydantoinase activity in whole cells and crude extracts of strains found to be positive with the spot test

Activity is given as $\mathrm{U}(\mathrm{g} \text { wet } \mathrm{wt})^{-1}$ for whole cells and $\mathrm{U}$ (mg protein) $)^{-1}$ for crude extract.

\begin{tabular}{|c|c|c|c|c|c|c|c|}
\hline \multirow[b]{3}{*}{ Strain } & \multirow{3}{*}{$\begin{array}{c}\text { Substrate ... } \\
\text { Spot } \\
\text { test }\end{array}$} & \multicolumn{6}{|c|}{ Hydantoinase activity } \\
\hline & & \multicolumn{2}{|c|}{ Dihydrouracil } & \multicolumn{2}{|c|}{ Hydantoin } & \multicolumn{2}{|c|}{ Isopropylhydantoin } \\
\hline & & $\begin{array}{l}\text { Whole } \\
\text { cells }\end{array}$ & $\begin{array}{l}\text { Crude } \\
\text { extract }\end{array}$ & $\begin{array}{l}\text { Whole } \\
\text { cells }\end{array}$ & $\begin{array}{l}\text { Crude } \\
\text { extract }\end{array}$ & $\begin{array}{l}\text { Whole } \\
\text { cells }\end{array}$ & $\begin{array}{l}\text { Crude } \\
\text { extract }\end{array}$ \\
\hline $\begin{array}{l}1-2 \\
1-9\end{array}$ & $\begin{array}{l}++ \\
++\end{array}$ & $\begin{array}{l}24 \cdot 65 \\
26 \cdot 3\end{array}$ & $\begin{array}{l}0.86 \\
1.1\end{array}$ & $\begin{array}{l}3.55 \\
4.15\end{array}$ & $\begin{array}{l}0.1 \\
0.13\end{array}$ & $\begin{array}{l}7.4 \\
8.75\end{array}$ & 0.22 \\
\hline $1-15$ & ++ & $21 \cdot 4$ & 0.03 & 0.55 & 0 & 1.55 & 0.03 \\
\hline $2-2$ & ++ & $31 \cdot 85$ & 1.86 & 6.25 & $0 \cdot 27$ & 3.85 & 0.92 \\
\hline $2-5$ & + & 33.55 & 0.42 & $4 \cdot 75$ & 0.07 & 3.65 & 0.1 \\
\hline $2-6$ & ++ & 0.05 & 0.014 & $0 \cdot 15$ & 0.04 & 0.25 & 0.16 \\
\hline $5-1$ & $\mathbf{w}$ & 0.75 & 0.003 & 1 & 0 & $1 \cdot 2$ & 0.02 \\
\hline $7-1$ & w & 0.7 & 0.003 & 0.85 & 0 & $1 \cdot 2$ & 0.02 \\
\hline $8-1$ & w & 0.35 & 0.044 & 0.4 & 0 & 0.6 & 0.01 \\
\hline $10-1$ & - & 0.65 & 0.001 & $1 \cdot 15$ & 0.02 & $1 \cdot 2$ & 0.01 \\
\hline $10-3$ & ++ & 1.95 & 0.03 & 23.55 & 0.33 & $2 \cdot 35$ & 0.03 \\
\hline $11-1$ & + & 0.25 & 0.26 & 0.4 & 0.29 & 0.25 & 0.41 \\
\hline $11-2$ & + & 0.45 & 0.32 & 0.45 & $0 \cdot 17$ & 1 & 0.42 \\
\hline $11-3$ & + & 0 & 0 & 0.25 & 0.09 & 0.35 & 0.14 \\
\hline $11-4$ & + & 0 & 0 & 0.35 & 0.17 & 0.55 & 0.29 \\
\hline
\end{tabular}

* ++ , Positive reaction (yellow colour within $5-10 \mathrm{~s}$ ) after $7 \mathrm{~h}$ incubation with substrate; + , positive reaction after $24 \mathrm{~h}$ incubation with substrate; $\mathrm{w}$, weak or slow reaction (development of colour after more than $10 \mathrm{~s}$ ) after $24 \mathrm{~h}$ incubation with substrate; -, negative reaction (no colour).

The highest hydantoin-hydrolysing activities were obtained when dihydrouracil was used as substrate (Table 2). Some false positive reactions (i.e. positive with the spot-test and negative with the cells and/or the crude extract) were observed with strains 11-3 and 11-4. One false negative reaction (i.e. negative with the spot-test and positive with the cells and/or with the crude extract) was observed with strain 10-1. Substrate specificity varied among the strains. Dihydrouracil was the preferred substrate for the strains possessing a high activity except strain 10-3 for which hydantoin was preferred. $p$-Hydroxybenzylhydantoin was poorly hydrolysed by all strains. Isopropylhydantoin was a better substrate than hydantoin but gave lower activity than dihydrouracil. Strains 1-2, 1-9, 1-15, 2-2, 2-5 and 10-3 possessed the highest activity and were selected for further screening (induction experiment).

Hydantoin induced enzyme activity in strains 1-2, 2-2 and 2-5, while isopropylhydantoin induced hydantoinase in strains 1-2 and 2-5 (Table 3). $p$-Hydroxybenzylhydantoin induced little, if any, activity, while uracil induced activity in strain 2-2. Hydantoinase levels in strains 1-2, 1-9 and 2-5 were increased slightly by dihydrouracil. The inducers tested had no effect on the hydantoinase activity of strain 1-15. No activity was found in the crude extract of strain 10-3 and very low levels in the crude extract of strain 1-15, confirming the results of Table 2.

Qualitative and quantitative analyses were made on the ultrafiltrate from the enzyme membrane reactor (Table 4). When isopropylhydantoin was used as substrate, the end-products of the hydantoin-hydrolysing activity of the six strains was $N$-carbamylvaline. No valine was detected before the nitrite treatment of $N$-carbamylvaline, indicating that none of the six strains possessed an active amidohydrolase able to convert $N$-carbamylvaline into valine (Olivieri et al., 1981). The percentage conversion of isopropylhydantoin in the membrane reactor was calculated for each strain at the point where maximum optical rotation value and maximum amount of $N$-carbamylvaline were reached during the continuous experiments. During these experiments no attempt was made to optimize the process with any of the six strains. The highest conversion rate $(44 \%)$ was obtained with strain $2-2$. Strains $1-15$ and $2-2$ produced the highest amount of $N$-carbamylvaline whereas $2-5$ and $10-3$ were very poor strains with regard to continuous performance in the membrane reactor. The D-stereospecificity of the enzyme was 
Table 3. Effect of inducers on hydantoinase production

The strains were grown in medium $\mathrm{K}$ containing one of the following inducers $\left(\mathrm{g} \mathrm{l}^{-1}\right): \mathrm{H}$, hydantoin; I, isopropylhydantoin; B, para-hydroxybenzylhydantoin; U, uracil; D, dihydrouracil. The crude extracts were then tested against isopropylhydantoin as substrate.

\begin{tabular}{|c|c|c|c|c|c|c|}
\hline \multirow[b]{3}{*}{ Strain } & \multicolumn{6}{|c|}{$\begin{array}{l}\text { Hydantoinase specific activity } \\
\left.\text { [U (mg protein })^{-1}\right]\end{array}$} \\
\hline & \multicolumn{6}{|c|}{ Inducer: } \\
\hline & $\mathrm{H}$ & I & B & U & D & none \\
\hline $1-2$ & 0.088 & 0.079 & 0.0115 & - & 0.027 & 0.013 \\
\hline $1-9$ & 0.005 & 0.024 & 0.011 & 0.015 & 0.021 & 0.006 \\
\hline $1-15$ & 0.008 & 0.007 & 0 & 0.013 & 0 & 0.053 \\
\hline $2-2$ & 0.133 & 0.038 & 0.020 & 0.362 & 0.003 & 0.038 \\
\hline $2-5$ & 0.096 & $0 \cdot 112$ & 0.022 & 0.006 & 0.123 & 0.065 \\
\hline
\end{tabular}

Table 4. Characterization of the ultrafiltrates from the enzyme membrane reactors

The crude extracts were incubated in membrane reactors containing isopropylhydantoin as substrate. The formation of the product $N$-carbamylvaline ( $N$-c-VAL) (found in the ultrafiltrate) was continuously monitored by polarimetry.

\begin{tabular}{|c|c|c|c|c|c|c|}
\hline \multirow[b]{2}{*}{ Strain } & \multirow{2}{*}{$\begin{array}{c}\text { Conversion } \\
\text { of isopropyl- } \\
\text { hydantoin } \\
\text { to } N \text {-c-VAL } \\
(\%)\end{array}$} & \multirow{2}{*}{$\begin{array}{l}\text { Optical } \\
\text { rotation } \\
\text { value } \\
(436 \mathrm{~nm})\end{array}$} & \multicolumn{2}{|c|}{$\begin{array}{l}N \text {-Carbamylvaline } \\
\left(\mathrm{mg} \mathrm{ml}^{-1}\right)\end{array}$} & \multicolumn{2}{|c|}{$\begin{array}{c}\text { Valine } \\
\left(\mathrm{mg} \mathrm{m}^{-1}\right)\end{array}$} \\
\hline & & & PABA* & AAA $\dagger$ & AAAt & D-AOD $\ddagger$ \\
\hline $\begin{array}{l}1-2 \\
1-9\end{array}$ & $\begin{array}{l}11 \cdot 0 \\
25 \cdot 3\end{array}$ & $\begin{array}{l}-0.125 \\
-0.162\end{array}$ & $\begin{array}{l}0.67 \\
0.68\end{array}$ & $\begin{array}{l}0.70 \\
0.74\end{array}$ & $\begin{array}{l}0.25 \\
0.40\end{array}$ & $\begin{array}{l}0.27 \\
0.42\end{array}$ \\
\hline $1-15$ & 26.0 & -0.281 & 1.11 & $\begin{array}{l}1.14 \\
1.14\end{array}$ & 0.66 & 0.42 \\
\hline $2-2$ & $44 \cdot 1$ & -0.255 & 1.31 & 1.36 & 0.67 & 0.70 \\
\hline $2-5$ & $8 \cdot 1$ & -0.025 & 0.22 & $<0.25$ & 0.08 & 0.08 \\
\hline $10-3$ & 8.5 & -0.051 & 0.33 & $<0.25$ & 0.14 & 0.14 \\
\hline
\end{tabular}

- $N$-Carbamylvaline determined with $p$-dimethylaminobenzaldehyde (PABA) as detection reagent.

$\dagger N$-Carbamylvaline or valine as determined with ninhydrin as detection reagent (amino acid analyser). Under our conditions, the sensitivity level for the detection of $N$-carbamylvaline was $0.25 \mathrm{mg} \mathrm{t}^{-1}$. Valine was obtained after hydrolysis of $N$-carbamylvaline with nitrous acid. This chemical conversion was not optimized.

$\ddagger$ Valine as determined enzymically with the amino acid oxidase (AOD) test (Boehringer). Under our conditions, the sensitivity of the $\mathrm{L}$ - or D-amino acid oxidase tests was $2.0 \mu \mathrm{M}$ and $1.0 \mu \mathrm{M}$ respectively. No $\mathrm{L}$-valine was detected in our samples.

checked by determining the chirality of the products $N$-carbamylvaline and valine using an enzymic test and TLC. Only D-valine was detected in the $N$-carbamyl amino acid hydrolysates. Using TLC, controls of D-and L-valine were detected but not isopropylhydantoin nor $\mathrm{N}$ carbamylvaline. Again the enantiomeric resolution by TLC confirmed that the six selected strains produced only $N$-carbamyl-D-valine.

\section{DISCUSSION}

The purposes of the present study were to select hydantoin hydrolysing micro-organisms rapidly and to evaluate the reliability of a spot-test used to detect such micro-organisms isolated from the environment under different conditions.

Relatively few strains were isolated by selective enrichment but a high percentage $(20 \%)$ were positive. This confirmed that the microbiological screening methods were efficiently oriented towards hydantoinase-producing micro-organisms. Good correlation between hydantoinase activity in whole cells and crude extracts of all strains found positive with the spot test previously described proved it to be a reliable screening method and a good indicator of the presence of hydantoinase. Our results (Table 2) showed that dihydrouracil was the best screening substrate 
for hydantoin-hydrolysing micro-organims, confirming previous observations (Morin et al., $1986 b$; Sun, 1983; Yamada et al., 1978).

Hydantoinase activity could be induced by a variety of compounds (Table 3). Instability or inactivation of the hydantoinase of strains 1-15 and 10-3 presumably occurred after cell disruption of these strains since low enzyme activity was observed (Table 2). We have no indication of the mechanism underlying this instability. However, these phenomena seemed to be attenuated when the enzyme was produced in a membrane reactor (Table 4). The binding of the hydantoinase to the membrane of the reactor could contribute to the stability of some hydantoinases, such as the one produced by strain 1-15. The importance of some ions for hydantoinase activity has been pointed out (Morin et al. 1986c; Sun, 1983; Syldatk et al., 1986; Yamada et al., 1978) and cannot be excluded in the case of strain 2-5, since the ions were washed off within the first $10 \mathrm{~h}$ in the membrane reactor. Instability and/or inactivation of hydantoinase has also been reported (Morin et al., $1986 \mathrm{c}$ ). Our results suggest that we are dealing with different types of hydantoinases. The hydantoinases produced by strains 1-2, 1-9, 2-2 and 2-5 are stable in a crude extract and in a membrane reactor, as observed for the $P$. fluorescens strain DSM 84 (Morin et al., 1986 c). The hydantoinases from strains 1-15 and 10-3, which were unstable after cell disruption, were stable in a membrane reactor.

The few false positive reactions observed with the spot-test may be due to the non-specificity of the $p$-dimethylaminobenzaldehyde reagent as reported by Morin et al. (1986a) or to the instability or inactivation of the hydantoinase in whole cells or in crude extracts. Most of the false positive reactions were observed with strains with very low hydantoin-hydrolysing activity (such as strains 11-3 and 11-4). The level of detection of the different $N$-carbamyl amino acids by Ehrlich's reagent differs, and this could be one of the explanations for the observed false negative reactions.

The screening method for hydantoinase-producing microorganisms described here has the following advantages. (1) Using the spot-test and selective isolation media and culture conditions should permit the rapid testing of a large number of strains from a wide range of environments. (2) Due to the reliable indicative value (presence of hydantoinase) of the spottest, isolated positive strains can be rapidly selected. (3) The spot-test also permits a selection of strains according to the time of appearance of detectable enzyme activity. A trained experimenter should also be able to select positive strains according to the intensity of the yellow colour. (4) The results in Table 4 demonstrate that a laboratory enzyme membrane reactor can be efficiently used in a screening programme. Such a reactor yields relatively pure products after low $M_{\mathrm{r}}$ compounds contained in the crude extract are washed out. In our experiments, $N$ carbamylvaline was the only $\mathrm{N}$-carbamyl amino acid detected in the ultrafiltrate of the strains tested.

A Morin was supported by Agriculture Canada, Centre de recherches alimentaires de Saint-Hyacinthe, Québec, Canada. We thank S. Löslein, P. Markwardt and I. Kristen for their valuable technical assistance.

\section{REFERENCES}

BRADFORD, M. M. (1976). A rapid and sensitive method for the quantitation of microgram quantities of protein utilizing the principle of protein-dye binding. Analytical Biochemistry 72, 248-254.

COTORAS, D. \& WAGNER, F. (1984). Stereospecific hydrolysis of 5-monosubstituted hydantoins. Proceedings of the 3rd European Congress on Biotechnology, Munich, vol. III, pp. 351-356. Basel: Verlag Chemie.

GǗnther, K., Martens, J. \& Schickedanz, M. (1984). Dünnschichtchromatographische Enantiomerentrennung mittels Ligandenaustausch. Angewandte Chemie 96, 514-515.

Hummel, W., SchütTe, H. \& Kula, M.-R. (1983). Large scale production of $D$-lactate dehydrogenase for the stereospecific reduction of pyruvate and phenylpyruvate. European Journal of Applied Microbiology and Biotechnology 18, 75-85.

LEUCHTENBERGER, W., KARRENBAUER, M. \& PlöCKer, U. (1984). Scale-up of an enzyme membrane reactor process for the manufacture of $\mathrm{L}$ enantiomeric compounds. Annals of the New York Academy of Sciences 434, 78-86.

MORIN, A., Hummel, W. \& KulA, M.-R. (1986a). Rapid detection of microbial hydantoinase on solid medium. Biotechnology Letters 8, 571-576.

Morin, A., Hummel, W. \& KulA, M.-R. (1986b). Production of hydantoinase from Pseudomonas fuorescens strain DSM 84. Applied Microbiology and Biotechnology 25, 91-96. 
Morin, A., Hummel, W., Schütte, H. \& Kula, M.-R. $(1986 c)$. Characterization of hydantoinase from Pseudomonas fluorescens strain DSM 84. Biotechnology and Applied Biochemistry 8, 564-574.

Olivieri, R., Fascetti, E., ANgelini, L. \& Degen, L. (1981). Microbial transformation of racemic hydantoins to D-amino acids. Biotechnology and Bioengineering 23, 2173-2183.

SuN, W. (1983). Screening of strains producing dihydropyriminidase and fermentation conditions. Weishengwu Xuebao 23, 133-142.

Syldatk, C., Cotoras, D., Dombach, G., Gross, C., Kallwass, H., Andree, H., Gebinoga, M. \& WAGNER, F. Metallo-dependence, incuuction, substrate- and stereospecificity of a microbial hydan- toinase. 17th Meeting of the Federation of European Biochemical Societies, Berlin (West), 24-29 August 1986.

Takahashi, S., OHashi, T., KII, Y., Kumagal, H. \& YamadA, H. (1979). Microbial transformation of hydantoins to $N$-carbamyl-D-amino acids. Journal of Fermentation Technology 57, 328-332.

Wandrey, C. \& Flaschel, E. (1979). Process development and economic aspects in enzyme engineering. Acylase L-methionine system. Advances in Biochemical Engineering 12, 147-218.

Yamada, H., Takahashi, S., KII, Y. \& Kumagai, H. (1978). Distribution of hydantoin hydrolysing activity in microorganisms. Journal of Fermentation Technology 56, 484-491. 